\title{
National Observatory on Special Education: Network Study about Inclusive Education in Brazil
}

\author{
Mendes Eniceia, Cia Fabiana \\ Department of Psychology, Federal University of São Carlos, São Carlos, Brazil \\ Email: eniceia.mendes@gmail.com
}

Received 18 July 2015; accepted 14 September 2015; published 18 September 2015

\begin{abstract}
Considering the importance of collaborative networks of research, a group of Brazilian researchers has created the National Observatory on Special Education (in Portuguese Oneesp), whose focus is on the production of integrated studies about policies and practices directed to the issue of school inclusion in Brazilian reality. The present project has focused on a nationwide study about a government policy to stimulate the creation of support services to students with special educational needs in regular schools, called "Multifunctional Resource Rooms (MRR)". According to official data, between 2005 and 2011 the Brazilian Ministry of Education had financed 30.000 MRR spread in all Brazilian states. To what extent this type of service has supported the education of children and young with educational special needs? To answer these questions 203 researchers from 16 Brazilian states, representing 22 universities are leading a network study to analyze the municipalities' implementation of this policy. Studies were conducted involving 58 municipalities for concurrently produce, knowledge and professional development through collaborative research, and were conducted through interviews with focus groups composed of approximately 450 MRR teachers, and then a national study survey in progress, directed to about 500 MRR teachers. The analysis of the results, still preliminary, indicated that the policies of the municipalities, despite following some guidelines from the Ministry of Education, were translated to their reality and assumed quite different local expressions depending in part on local history of the development of services of special education in determined reality.
\end{abstract}

\section{Keywords}

Special Education, Inclusive Education, Educational Policy, Brazil

\section{Introduction}

The issue of inclusive education has raised a worldwide heated debate in the last 30 years, including Brazil. As pointed out by Sowell [1], currently, there is an ideological division amongst scholars. One side is represented by those who strongly advocate in favor of a more radical kind of inclusive education, whose position has been 
hegemonic for orienting public policies. On the other side, the representatives are those that show different levels resistance, extreme caution or even rejection to inclusion. Therefore, the area of Special Education is immersed in tensions between those who argue towards the need of a radical change, in opposition to those who recommend a more cautious approach based on empirical analysis and historical considerations [2] [3].

In Brazil, the Federal Constitution of 1988 [4] and the assumptions about inclusion contained in the National Education Basis and Guidelines Law [5] appeared in refereed initiatives aim to reform Brazilian educational system. The article 58 of National Educational Law [5] establishes that the enrollment of pupils with special education needs should, preferably, be provided in the mainstream system, so that this guidance that have led Federal Government, States and Municipalities to adopt public policies that guarantee the rights to education for these pupils: those with disabilities, pervasive developmental disorders and high ability/gifted. These official documents legally entitle the targeted population of pupils with special education to universal access to education as well as equality of opportunities in mainstream schools, as any other children. However, permanence in schooling and academic success will only be possible if mainstream schools change and commit towards meeting special educational needs of these students.

The National Policy on Special Education from the Perspective of Inclusive Education [6], from Ministry of Education (MEC) reinforces the principles of inclusive schools, the right to be educated together with his/her colleagues without disability by receive support from Specialized Educational Services (SES).

The Decree 7.611/2011 [7] defined Specialized Educational Services (SES) as a set of activities, with accessibility and pedagogical features institutionally and continuously organized, provided complementary or supplementary additional training for students in regular education. Under article 5 the decree specified that the MEC would provide technical and financial support to the following actions to offer specialized education, among others that meet the objectives set forth herein:

1) Enhancement of specialized educational services already offered;

2) Implementation of multi-functional resource classrooms;

3) Continued teacher education, including the development of bilingual education for deaf or hearing impaired students and the teaching of Braille for blind and low vision students;

4) Training managers, educators and other school professionals of education in the perspective of inclusive education, particularly in learning, participation and the creation of interpersonal bonds;

5) Architectural suitability of school buildings for accessibility;

6) Development, production and distribution of educational resources for accessibility, and

7) Structuring of core accessibility in federal institutions of higher education.

This decree also specifies that SES can be provided by both mainstream schools and specialized institutions. In mainstream schools, particularly, the appropriate setting with material (furniture, equipment, leaning material) and human resource (specialized teacher) for delivering this provision is called Multifunctional Resource Rooms (MRR).

In order to disseminate this policy all over the country, in 2005, the Ministry of Education launched the "Multifunctional Resource Rooms Program" with the view to support municipal educational systems in the implementation of MRR for the offer of ESE, complementary or supplementary schooling. According to official data, between 2005 and 2011, 39.301 MRR have been implanted in the majority of the 4.564 Brazilian municipalities and the Federal District. This process is based on the enrollment of students registered in the annual Education School Census.

The education legislation prescribes that the SES should preferably arrange for the provision of Multifunctional Resource Rooms (MRR), so that the target audience of students in Special Education does not interrupt their school careers in the common class, but at the same time is able to meet their demands for schooling. Is the MRR able to meet the needs of all students target of Special Education? To answer this question 25 researchers from 22 universities and 18 graduate programs have joined to carry out the Oneesp Project.

\section{Method}

The demand for the creation of collaborative research networks in Special Education has emerged in several meetings of researchers over the past five years in Brazil, and several inter-institutional research groups have been formed collaborative partnerships in search of knowledge production. The National Observatory for Special Education (Oneesp in Portuguese) is one of those networks that had its original proposal outlined by the 
Research Group on Human Resources Preparation GP-Foreesp-http://www.gpforeesp.ufscar.br ) from the Federal University of São Carlos.

During the year 2011 was established the national network consisting of up to three researchers for each state from each of the 17 Brazilian states (Alagoas, Amapá, Bahia, Espírito Santo, Goiás, Maranhão, Mato Grosso do Sul, Minas Gerais, Rio de Janeiro, Rio Grande do Norte, Rondônia, São Paulo, Santa Catarina, Sergipe, Paraíba, Paraná). In addition, the state networks were established with university researchers interested in conducting studies in their locality.

The first meeting of the national network was conducted to provide the socialization of knowledge about the different realities in the states and plan to conduct local studies. 36 researchers of the national network participated in this meeting, all of which came with a mission to: 1) socialize the information related to the project in state schools, 2) negotiate project development in their municipalities, 3) complete the establishment of municipal networks, 4) characterize the policies of inclusive education municipalities. The establishment of local research networks involving university researchers who were part of the state system, teachers of multi-functional resources classrooms and, where possible, municipal managers of common and special education in the municipality.

In 2012 the second meeting of the national network was made, with the participation of 45 members. Given the continuation of the study at this meeting was discussed the methodology of local studies based on interviews with focus groups. The scripts with the triggering questions for data collection with focus groups were refined. The studies at municipal level with meetings with teachers of resource rooms classrooms was begun for conducting focus groups about the topics covered in the project, basing on the methodology of collaborative research that aimed to produce knowledge and training of those involved. The triggering questions for discussions in the focus groups addressed three topics: the student assessment, teacher training and functioning of the MRR.

In 2013 the third meeting of the national network was made, with the participation of 88 members so it was possible to disclose the first results of the studies within the municipalities and was produced with 64 full papers related to local project developed by members of Oneesp. On this occasion the first syntheses were produced, still provisional, the results of projects in different regions.

In addition, one survey online nationwide was developed to collect more data with teacher's multifunctional resources rooms across the country. Further details about the methodology are on the site http://www.oneesp.ufscar.br.

The project the project began with 25 researchers. Subsequently the network has grown so to 808 participants: 203 researchers (49 of the national network of 72 state research networks, 82 associated researchers); 217 students (142 students in 22 undergraduate, 75 of 14 different graduate programs); 446 specialized teachers that worked in the MRR and 36 municipal administrators of special education from form 17 Brazilian states.

\section{Results and Discussion}

Data from the National Observatory of Special Education Project (Oneesp) have been organized in a central database at the Federal University of São Carlos which consists of:

1) About 300 documents have being analyzed, based on which the State of Art has been elaborated, out of which 30 are official documents (from the Ministry of Education that provide the legal guidelines for the MRR service), 18 journal articles, 70 dissertations and theses, and 180 papers published in national and international scientific events,

2) Focus Groups with teachers of 56 municipalities, have been led by the national research network, transcribed and turned into a database consisting of 4300 pages,

3) A database consisting of 500 pages of transcribed interviews have been led with 36 municipal Special Education Managers, transcribed and typed into electronic file,

4) About 1200 forms filled in an online survey for MRR teachers.

Therefore, the project has produced a large Qualitative Database whose analysis is a challenge for the National Network of Oneesp researchers. The focus now is to adapt, enhance and develop computational techniques that could favor qualitative analysis, complement quantitative analysis with the view to conducting data analysis in the field of Special Education. Thus, considering that the project is still in progress should be noted that the results reported here are preliminary, since many data have not yet been systematized nationally. To present these preliminary results we synthesize them around the three axes of the project. 
Regarding the assessment of the student, the study confirms the findings of several other studies that indicate that the policy of inclusion in Brazilian school has various problems due to the lack of precise guidelines for assessment for identifying and defining eligibility for services from students audience of Special Education [7], the assessment for the planning of teaching for these students through the development of a plan individually tailored to meet the needs of these students [8]. and, finally, in the assessment process for monitoring the process of teaching and learning through formal and informal standardized measures and performance to achieve a successful educational journey [9].

Regarding the organization of the specialized services, given the recently of the proposed deployment of these services and the growth in the number of MRR around the country, we sought to investigate how teaching is being structured in such spaces. Evidences indicates that the MRR in general cannot answer it, generally for one or two hours of care in alternate shift , the different needs of various children, who generally only come to school at six years of age, with no minimum requirements and now with considerable delays in development. One difficulty has been appointed to organize the service by the same teacher for students with disparate ages and disabilities. In relation to understanding that teachers had about that service, data generally indicate the existence of significant challenges regarding a definition on how Specialized Educational Services should be conducted within the MRR, and even more in the relationship between the MRR and the curriculum of the regular classroom. However, the main problem seems to be the political conception of the support service based in MRR, which becomes the locus of accommodation of difference, which still focuses on student disabilities and their care, causing little or no impact on a school that needs to change to offer quality education for all.

Regarding teachers' training, the evidence confirms the shortage of specialist teachers, managers with complaints about the lack of competent teachers, who are often met with the allocation of untrained teachers in the area. The study still found a huge demand for training for both special education and regular teacher, which is being supplied by the government in distance education courses of short duration.

\section{Conclusions}

Given the current context of the Brazilian school inclusion policy, two major issues mobilized the attention of national researchers in frequent forums to discuss the area of Special Education: How to produce knowledge to advance policies and practices of school enrollment in the country? How to improve links between the knowledge that is being produced and decisions in educational policies related to the prospect of school inclusion? To answer these questions a collaborative network of research team called Special Education National Observatory (In portuguese, Observatório Nacional de Educação Especial-Oneesp) was established. The goals with the creation of Oneesp were to establish a collaborative network of researchers to enhance the production of substantial medium-term information and knowledge needed to improve decisions regarding school policies and education systems, and to provide the opportunity for sharing of experiences among researchers to improve the system of knowledge production and development of personnel in the area of Special Education.

In recent decades there has been a revolution in the way science has been conducted and the essential points of change are the collaborative networks and intensive use of information and communication technologies (ICTs). The project Oneesp has produced a huge amount of qualitative data and just now we seek to build the collaboration among researchers from the Special Education and Computational Science areas to integrate their efforts and competences.

The Oneesp project has still not been concluded that the preliminary results are amazing and extrapolate much what is expected because in three years its impact has already been seen in order to:

1) Contribute to the advancement of municipal policies of local school inclusion from the collection and systematization of information that supports decision-making, allowing, for example, identify demands for the training of teachers, limits and possibilities of MRC, performance monitoring target population of students in Special Education at school, etc.;

2) Strengthen ties between universities and the Municipal Education expanding opportunities of the university produce knowledge that contributes to advancing policies and practices;

3) Provide ongoing training for specialist teachers who work in MRC in public schools;

4) Provide training to all researchers and students involved in collective and collaborative production of typical knowledge networks research contexts;

5) Provide an opportunity for exchange and training among members of research groups from 22 Brazilian 
universities that have special education as an object of study and thereby strengthen national scientific production in the area of Special Education, and finally.

6) Increase the impact of scientific knowledge in policy of school inclusion within the municipalities, states and the country.

In relation to the main findings, to date the results have pointed out that although the instruments that force the standardization of school inclusion policy by the Ministry of Education, in the context of municipalities that policy ends up suffering multiple translations and at various levels, so that local policies end up taking different contours.

\section{Acknowledgements}

CNPq/Capes-Obeduc/Capes-Proesp.

\section{References}

[1] Sowell, T. (1995) The Vision of the Anointed: Self-Congratulation as a Basis for Social Policy. Basic Books, New York.

[2] Meredith, B. and Underwood, J. (1995) Irreconcilable Differences? Defining the Rising Conflict between Regular and Special Education. Journal of Law and Education, 24, 195-226.

[3] Gonçalves, M.E. (2006)A radicalização do debate sobre inclusão escolar no Brasil. Revista Brasileira de Educação, 11, 387-405. http://dx.doi.org/10.1590/S1413-24782006000300002

[4] Brasil (1988) Constituição Federal. DF, Brasília.

[5] Brasil (1996) Lei $n^{\circ}$ 9.394, de 20 de dezembro de 1996. Estabelece as diretrizes e bases da educação nacional. Diário Oficial [da] República Federativa do Brasil, Brasília, 23 de dez. 1996. Seção 1.

[6] Brasil (2007) Política de Educação Especial na perspectiva da Educação Inclusiva. Disponível em Ministério da Educação/Secretaria de Educação Especial. http://portal.mec.gov.br/arquivos/pdf/politicaeducespecial.pdf

[7] Brasil (2011) Decreto $n^{\circ}$ 7.611, de 17 de dezembro de 2011. Dispõe sobre a educação especial, o atendimento educacional especializado e dá outras providências. Presidência da República/Casa Civil/Subchefia para Assuntos Jurídicos, Brasília. http://www.planalto.gov.br/ccivil 03/ ato2011-2014/2011/decreto/d7611.htm

[8] Veltrone, A.A. (2011) Inclusão escolar do aluno com deficiência intelectual no Estado de São Paulo: Identificação e caracterização. Tese de Doutorado, Programa de Pós-Graduação em Educação Especial, Universidade Federal de São Carlos, São Carlos.

[9] Tannús-Valadão, G. (2010) Planejamento educacional individualizado: Propostas oficiais da Itália, França, Estados Unidos e Espanha. Dissertação de Mestrado. Programa de Pós-Graduação em Educação Especial, Universidade Federal de São Carlos, São Carlos. 